\title{
THE RULER AND HIS NOBLE SUBJECT: THE COMMUNICATION MODEL OF THE CORRESPONDENCE BETWEEN SIGISMUND AUGUSTUS AND MIKALOJUS RADVILA THE RED, 1546-1572
}

\section{RAIMONDA RAGAUSKIENE்}

\section{Lithuanian Institute of History, Vilnius}

'I will tell you once more about those two Mikalojuses (the Black and the Red) that the king of Poland Sigismund Augustus valued them greatly with only one difference - he took care of and protected Radvila the Red, that is, he loved the Red greatly, and the Black was honoured and valued' - thus the biographer of Boguslovas Radvila describes the attitude of Sigismund Augustus towards the famous Radvilas. ${ }^{1}$

Friendship and mutual understanding existed between the king and Radvila the Red after Sigismund Augustus became Grand Duke of Lithuania in 1547 and these got even stronger after his marriage to Radvila's sister Barbora, and changed only a litlle after her death. However, what do the words 'greatly loved' and 'honoured' mean, how do they reflect the relationship between the king and the Radvilas? Is the relationship between the king and the Radvila, like the traditional communicative model between the ruler and his subjects or the communication of a closer, personal kind? ${ }^{2}$ Our aim is to examine the model of their communication, how it changed and for what reasons.

Examining the role of Mikalojus Radvila the Black (15151565), the Polish historian Józef Jasnowski established what

${ }^{1}$ According to J. Łukaszewicz. Dzieje kościołów wyznania helweckiego w Litwie. T. 1, Poznań, 1842, 11.

${ }^{2}$ In this article communication is understood as any kind of relationship among people connected with giving information excepting a sender (coder) and interpreter (decoder) and also information (letters). 
the Sigismund Augustus-Radvila Black type of communication was. ${ }^{3}$ Early and later historiography paid attention to the person of Radvila the Red, but there is still no general work devoted to political, religious and cultural role of this nobleman in the sixteenth-century Grand Duchy of Lithuania. ${ }^{4}$

The contemporaries of Radvila the Red regarded his role differently. They were interested even in the smallest changes in the ruler's behaviour towards this nobleman. For the client that meant the strength of his patron, for the foreign diplomats division of powers inside the country, and for the family - the stability of its status. This was reflected in the occasional literature of those times, in the reports of various messengers ${ }^{5}$ and in an abundant correspondence.

The correspondence of Radvila the Red and Sigismund Augustus can reveal the model of communication between them. The researcher of this theory Stefanija Skwarczyńska excepted this fact as the main trait of the letter that the letter is a reflection of some kind of relationship between two persons, strained through subjective 'me' in the given time. ${ }^{6}$ So, the classic communicative scheme 'addresser - text - adressee' gets the most precise power of the communicative model 'king - nobleman'.

\section{${ }^{3}$ J. Jasnowski. Mikokij Czamy Radziwitt (1515-1565). Warszawa, 1939,} 394-396. According to Jasnowski, one of Radvila the Black's aims was to gain the king's favour. He tried to be a devoted subject, without regard for his person or his wealth, but he received much in return for such 'sacrifices'. Radvila the Black was especially afraid of cold relationships. However, political disagreements led to royal distance. Generalizing their model of communication: at the beginning he was a like-minded, consistent adviser; at the end of his life he was still 'well-beloved and from habit the king listened to his advice, but he 'did not hear.'

${ }^{4}$ J. Jasnowski.Mikołaj Czarny Radziwitł; H. Łulewicz, Radziwiłł Mikołaj 'Rudy'. Polski Stownik Biograficzny, t. 30, Wrocław, etc., 1987; Z. Kuchowicz, Barbara Radziwitlówna, Lódź, 1976 (Lithuanian translation: Z. Kuchovičius, Barbora Radvilaité, Vilnius, 1991); E. Kotłubaj, Galerja Nieświeźska portretów Radziwittowskich, Wilno 1857 (Lithuanian translation: E. Kotlubajus, Radvilos, Vilnius, 1995); Mikołaj Radziwiłł 'Rudy', Hetmani Rzeczypospolitej obojga narodów, Warszawa, 1995. Among the newest works see: A. SucheniGrabowska. Zygmunt August król polski i wielki książę litewski 1520-1562, Warszawa, 1996; Miscellanea Historico-Archivistica, t. 7, Warszawa, 1997.

${ }^{5}$ R. Ragauskienè. Mikalojus Radvila Rudasis XVI amžiaus proginéje literatūroje. Lituanistica, nr. 2, 1996, 41-43; Sucheni-Grabowska. Zygmunt, p. 141.

${ }^{6}$ S. Skwarczyńska. Teoria listu. Lwów, 1937, 26, 45, 46. 
The aim of the article is to establish which communicative model most closely fits the reality of relations between Sigismund Augustus and Radvila the Red. In 1547 when the young Radvilas (Mikalojus the Black, his brother Jonas and cousin Mikalojus the Red) entered the Council of Noblemen of the Grand Duchy of Lithuania they were, politically speaking homines novi. When the last Jagiellonian died in 1572, Radvila the Red was the leading senator of the Grand Duchy of Lithuania, Vilnius Voivode, Chancellor of the Grand Duchy of Lithuania, and the owner of a large estate. The communication model between Sigismund Augustus and Radvila the Red can help to clear out the reasons of such a rise to prominence and assert the significance of the 'Barbora factor'.

In this case one can not complain of a lack of sources. Approximately 200 items of correspondence between Sigismund Augustus and Mikalojus Radvila the Red remain extant. They were preserved carefully. Radvila was even somewhat of an archivist. He took good care of all letters that he received. Sometimes he himself underlined surnames, put crosses in the margin of the text, wrote notes ${ }^{7}$ and dorso wrote the names of the sender and deliverer. He did not burn letters even if they were dangerous to the addressee. ${ }^{8}$ Royal correspondence was especially important to the family. This showed the importance

${ }^{7}$ Cf. the underlined surnames (Feb. 27, 1549. Kraków. A letter of Mikołaj Trzebuchowski to Radvila the Red, AR, dz. V, t. 408, nr. 16509), the ticks that are put at the edge of the text (Feb. 23, 1570. Warszawa. A letter of Maciej Sawicki to Radvila the Red. Archiwum Radziwiłłów (henceforth AR), dz. V, t. 344, nr. 13980), other notes (a greeting speech of Barbora in Kraków is evaluated as 'dobre, mąndre i roztropnie' (Feb. 17, 1549. Kraków. Stanisław Pieniąnrzek to Radvila the Red, AR, dz. V, t. 268, nr. 11648), dorsal notes ( on the letter of Trzebuchowski it is written in hand by Radvila himself "strange Shrovetide letter’ (March 14, 1549, Kraków. A letter of M. Trzebuchowski to Radvila the Red, ibidem.

${ }^{8}$ In the last months of Sigismund Augustus' life everybody tried to profit: to get stewards, lands from the king. In spite of king's disagreement M. Sawicki, the client of Radvila the Red, invited the Chancellor to come to the court immediately. In the letter from Knyszyn he wrote about a bad state of king's health, intrigues in the court and said that if he did not hurry it "can be too late.' He asked to burn that letter which was full of trust because 'iedno Fedorek czalo dojachal z nim, bo gardło moie na łyszku by musiało bycz' (June 29, 1572. Knyszyn. M. Sawicki letter to Radvila the Red, AR, dz. V, t. 344 , nr. 13980). 
of the addressee and his family. Radvila collected and saved all king's letters carefully, even those which had been written by Sigismund Augustus with great trust and where the king had asked him either to burn or to tear them up. ${ }^{9}$

In the course of time this correspondence came to be scattered in many different archives for a variety of reasons: in Raczyński Library in Poznań, ${ }^{10}$ the Main Archives of Early Acts in Warsaw and in P. Dubrovski's collection in the Russian National Library in St. Petersburg. ${ }^{11}$ A great part of the correspondence was published in the nineteenth century. Irena Kaniewska ${ }^{12}$ discussed published sources in the context of all Sigismund Augustus' Polish correspondence. One must agree with this scholar's conclusion concerning the doubtful academic value of certain publications. Despite certain editorial slips great accuracy was maintained in the publications of S. Lachowicz, A. Przeżdziecki and J. Jasnowski.

The problem at hand requires us to look not only at the content of the letters, but also at their form, techniques of communication, and the authorship of the letters.

The Intensity of Correspondence, the Problem of Authorship

It is difficult to give an exact number for the surviving correspondence, since the material is scattered in different archives, and there is also the problem of the number of extant copies. According to approximate data, 180 letters of Sigismund Augustus to Radvila the Red survive as against only 15 letters sent by Radvila the Red to his king. Generally Radvila the Red had an exceptional position in comparison with other recipients of royal letters. Over 300 letters survive from the king to other subjects.

In 1548-51 correspondence was intensive. Radvila the Red received 106 (62 per cent of the total number) private letters from Sigismund. Very little information survives from 1552-1572. Royal donations, received stewards could show agreement between those two persons. The average number of letters was

${ }^{9}$ F. Pułaski. Listy Barbary Radziwiłłówny. Z wieku Mikołaja Reja. Księga jubileuszowa 1505-1905. Warszawa, 1905, 58.

${ }^{10}$ Microfilms: Warszawa, Biblioteka Narodowa (henceforth $\mathrm{BN}$ ), mf. nr. 3659, 3654.

${ }^{11}$ Microfilm: BN, mf. nr. A1927.

${ }^{12}$ I. Kaniewska, Niektóre zbiory listów polskich króla Zygmunta Augusta, Odrodzenie i Reformacja w Polsce, t. 33, 1988, 91-107. 
exceeded only in 1562 at the time of the conflict between the Grand Duchy of Lithuania and the Grand Duchy of Moscow. Radvila the Red received 12 letters at that time.

The hand writing of the letters reveals an exceptional attitude on the king's part towards his brother-in-law. Sigismund Augustus did not like to write himself. There are only five letters written in the king's hand and they all are addressed to Radvila the Red. ${ }^{13}$

Did Radvila the Red have his own chancery? What were its functions, what was its influence in writing different documents, correspondence? The information provided by the sources is fragmentary and many documents are only signed by Radvila. Perhaps, at the beginning he used scribes in the service of his father, Vilnius Castellan Jurgis Radvila (ca. 1480-1541), and later he had his own chancery. There are only a few documents signed by Radvila scribes: in 1550 by Shostovitskii, ${ }^{14}$ in 1554-K. Drozha ${ }^{15}$ and St. Bartosziewicz. ${ }^{16}$ After he became the Voivode of Vilnius and the Chancellor of the Grand Duchy of Lithuania (1565) he used scribes from the chancellor's chancery.

Whether Radvila wrote himself or dictated, depended on the status of the addressee and the importance of the matter at hand. There are about 40 letters left to different addressees which mostly had been dictated by Radvila. ${ }^{17}$ Radvila the Red wrote himself or dictated letters to the king.

The style and deliberations of the letters were ironically called 'syllogism' by Sigismund Augustus, and that gives us no ground to doubt the authorship of Radvila. A slight change in

${ }^{13} A R$, dz. II, nr. 23; Kaniewska, Niektóre, p. 105; W. Pociecha, W. Taszycki, A. Turasiewicz, Listy w języku polskim pisane z czasów Zygmunta Augusta (1548-1551), 27, Biuletyn Biblioteki Jagiellońskiej, 1977, 73.

${ }^{14}$ Feb. 23, 1550. Vilnius. Radvila the Red letter to Jan Shimkovich, AR, dz. XI, nr. 19.

${ }^{15}$ Apr. 12, 1554. Valkininkai. Radvila the Red letter to Jan Hornostaj, LMAB, f. 256, nr. 2415.

${ }^{16} \mathrm{~S}$. Bartosziewicz was Hetman Radvila's scribe for a long time. On Jan. 12, 1567 the Voivode of Vilnius got him the post of the royal secretary, LM, 51, 1. 54.

${ }^{17} \mathrm{AR}, \mathrm{dz}$. IV, t. 34, kop. 495-496. In reality there were more letters written in Radvila's handwriting. Noblemen (Radvila the Black, J. Zamojski, F. Zebrzydowski and others) and clients thanked him for such letters. This is also attested by Radvila's rather developed handwriting. 
the handwriting of the letters should not deceive anyone. ${ }^{18}$ The handwriting became wider and not so uniform perhaps as a result of worsening eyesight and old age. The letters were written on large sheets of paper with water marks. There were no corrections and an omitted idea was sometimes inserted in the text, marked with a cross, and correspondingly that insertion was repeated in the margins. The text of original letters is put aesthetically and orthographically.

\section{The Technique of Communication}

The correspondence of Sigismund Augustus and Radvila the Red circulated via their personal messengers whom the sources called komornik, sluzebnik or pacholek. They delivered the correspondence of the king and Radvila in such ways as:

1) Radvila the Red - messengers - the king,

2) Radvila the Red - messengers - Barbora Radvilaite, other noblemen - the king,

3 ) the king - messengers - Radvila the Red.

As we see, Radvila the Red's letters reached the king in two ways-either directly or through mediators. Though there is not much information in the letters about messengers, we can speak about some kind of a postal service.

Table 1 Messengers of Radvila the Red and Sigismund Augustus in $1547-1571$

\begin{tabular}{|l|l|l|l|}
\hline Year & Messenger & In service of & Source \\
\hline 15480122. & Olexander & Radvila the Red & AR, dz. IV, t. 29, kop. 496 \\
1548. & Zulenski & Sigismund Augustus & BN, mf. nr. 3659 \\
15480725. & Graiewski & Radvila the Red & BN, mf. nr. 3659 \\
15490218. & Ponieczki & Radvila the Red & AR, dz. III, nr. 29. \\
15490221. & Szymka & Radvila the Red & AR, dz. III, nr. 29 \\
15490228. & Falczewski & Sigismund Augustus & BN, mf. nr. 3659. \\
15490703. & Quileczki & Radvila the Red & Chmiel, Rachunki, p. 293. \\
\hline
\end{tabular}

${ }^{18} \mathrm{Cf}$. Rūta Čapaitė on the character of the handwriting of Lithuanian cultural workers in the 19th century. Jurgio Ambraziejaus Pabréžos, Juozo Butavičiaus, Simono Daukanto braižai ir charakteriai (Handwritings and characters of Jurgis Ambraziejus Pabréža, Juozas Butavičius and Simonas Daukantas) Lietuviu atgimimo istorijos studijos. Asmuo: tarp tautos ir valstybés. Vilnius, 1996, 114. 
Cont.

\begin{tabular}{|c|c|c|c|}
\hline Year & Messenger & In service of & Source \\
\hline 15491023 & Baka & Sigismund Augustus & AR, dz. III, nr. 29. \\
\hline 15491108 & Paczkowski & Sigismund Augustus & AR, dz. III, nr. 29. \\
\hline 15500304 & Nieszyka & Radvila the Red & Baliński, Pisma, t. 2, p.200. \\
\hline 15500324 & Antoni Labęcki & Radvila the Red & Baliński, Pisma, t. 2, p.105. \\
\hline 15500426 & Ostrowski & Radvila the Red & BN, mf. nr. 3659 . \\
\hline 155004. & Żeligowski & Radvila the Red & Baliński, Pisma, t. 2, p. 128. \\
\hline ca. 155004 & Wierzbieta & Sigismund Augustus & AR, dz. .IV, t. 34, kop. 496. \\
\hline 15500526 & Jermola & Barbora Radvilaitè & AR, dz. III, nr. 29. \\
\hline 15510525 & Lewon & Sigismund Augustus & Baliński, Pisma, t. 2, p.246. \\
\hline 15520415 & Wojna & Sigismund Augustus & BN, mf. nr. 3654 . \\
\hline 1553039. & Narbut & Sigismund Augustus & BN, mf. nr. 3654 . \\
\hline 1565.1114 & Raioczki & Radvila the Red & BN, mf. nr. 3654 \\
\hline
\end{tabular}

The functions of messengers, the word pan describing them show that they were noblemen who could write and were familiar with some form of etiquette; no peasant would be allowed to get close to the king. And the correspondence of nobles was brought by noblemen. In a letter of 1565 from the bishop Mikalojus Pacas to Radvila the Red, the bishop apologizes to Radvila that the letter was delivered by a simple peasant. ${ }^{19}$ Other sources allow us to confirm the noble status of two messengers Ivanas Jarmola and Antonius Lambeta - the first had a seal with his coat of arms and the latter held some estate in Lutsk district..$^{20}$

The messengers had to fulfil other functions apart from delivering letters. They had to pass on especially important information orally ${ }^{21}$ they also had to retell the events they had

${ }^{19} \mathrm{Ca} .1565$. Geranainys. A letter of bishop Pacas to Radvila the Red, AR, dz. V, t. 252, kop. 11213, 'bom swych tak rychlo spadszy s konia dosiącz nie mógł, a też iusz nieraz onego ku w.m. slalem wiedaie, że posciwi szliachcici a ja za zle niemiewam, chocia do mnie y w kurpiech chlopy naszaią listy'.

${ }^{20}$ Apr. 13, 1552. Mortgaging Radvila the Red's estate, LMAB, f. 273, nr. 2062; Dec. 3,1549. The donation act of Radvila the Red's estate, AR, dz. XI, nr. 19, k. 61 .

${ }^{21}$ M. Baliński, Pisma, t. 2, p. 106; The king wrote: 'concerning other important affairs[...] you will understand everything from your servant Labęcki'. 
seen to the addressee, to carry money,,$^{22}$ various goods ${ }^{23}$ or accompanied important personages on their journey.

The work of messengers was very complicated and often dangerous. They had to be physically strong because they had to ride long distances as soon as possible. For example, the letter which was written by Radvila the Red on May 18, 1551 reached the king on May 25 in Proszewice (4 miles from Kraków). That means that the messenger had to ride a distance of 600 kilometres in eight days. ${ }^{24}$ It is very clear that the speed of delivery depended on the state of roads and various times of the year. The trips were dangerous because of attacks, epidemics and diseases. The messenger Nieszyka ${ }^{25}$ almost drowned 'u Mohily' and had to return to Kraków with the kings letter to Radvila. In 1553 the king asked Radvila to take care of the messenger who was going to him to Biržai at a time when there was plague in the Grand Duchy. ${ }^{26}$ The Castellan of Trakai, Eustachijus Valavičius' letter to Radvila reveals how dangerous the work of a messenger is. It informs us that the letters which had been sent by the Chancellor were found 'przy czlowieku zabitym naliezono w ymenieniu w. m., w tey torbie milostiwy panie acz byly listy i do mnie pisanie.... ${ }^{27}$ For these reasons they were very highly appreciated and their work was very reasonably paid. Their travelling allowance depended on the length of the journey and was from two to five golden coins. ${ }^{28}$ Apart from daily allowances the register speaks of the payment of a 'tip' (ex gratia). ${ }^{29}$

The messengers mostly were very trustworthy people who knew a lot including how to keep secrets. When Radvila the Red

${ }^{22}$ Apr. 26, 1550. S. Koszutski wrote to Radvila the Red: 'Ostrowskiego sam odsylal, a potem w. m. takiego drugiego posla niemial, któryby taką sumą zanieść był miał, boby jej na konie nie zawiózł żaden' -in Baliński, Pisma, t. 2, p. 115.

${ }^{23}$ In 1553 Sigismund Augustus asks Radvila to send him 'hutasy husarskie' for horses through his messenger, May 11, 1553. Kraków, A letter of Sigismund Augustus to Radvila the Red, BN, mf. 3654, k. 42.

${ }^{24}$ Baliński, Pisma, t. 2, p. 246.

${ }^{25}$ Ibidem, p. 202.

${ }^{26}$ Sept. 29, 1553. Opoczno. Sigismund Augustus letter to Radvila the Red, BN, mf. nr. 3654, k. 44.

27 Apr. 4, 1571. Warszawa. Castellan of Trakai E. Wołowicz letter to Radvila the Red, AR, dz. V, t. 451, nr. 17959.

${ }^{28}$ Rachunki dworu królewskiego 1544-1567, wyd. A. Chmiel, Kraków, 1911, 293.

${ }^{29}$ Ibidem, p. 293. 
got angry with his cousin Radvila the Black, an unfriendly attitude was expressed towards Radvila the Black by the kings brotherin-law's messenger, Jermola. ${ }^{30}$ There were messengers who liked to get drunk. M. Sawicki wrote of one Gramacki - he was afraid that after giving him a message about the situation in the king's court, the messenger 'might go for some beer'. ${ }^{31}$

Some problems with sending correspondence were of a more practical nature. Radvila tried to write more often and he was sometimes warned: "do not write more to us because we will have no one to give the letter to and besides we will not have anyone to write the letter to you; when we travel from Sandomierz we will have neither the marshal nor Kęsgaila with us' ${ }^{32}$ The king warned his brother-in-law through Radvila the Black to write less frequently - 'that you should not write so often because it is expensive and it is also very difficult with messengers in Radom' ${ }^{33}$ On occasions Radvila the Red wrote in his letters that he was 'sad that he still has not received any desired instruction' from the king. ${ }^{34}$

The second way of sending letters (through mediators) was a little longer, but more effective, as when Radvila the Red acted through his sister Barbora, noblemen and his whole clientage network. Radvila sent letters addressed to the king, to the above mentioned persons or some instructions about the king and his business through various messengers. ${ }^{35}$ In the first case they had

${ }^{30}$ Aug. 15, 1548. Korczyn. Radvila the Black letter to Radvila the Red, AR, dz. IV, t. 34, kop. 497; Radvila the Black wrote: 'ja nie wiem z kąd ta laska w. m. przeciw temu łotrowi Jarmole, (...) ale mnie tego żal, że mi się ta niechuć od w. m. pokazuje, nie chcę się zabierać w pismo wszakoż to w. m. wiedzieć racz żem siła pieniędzy poterał na teje dzisziejszej służbie z którei jadę wziawszy w zysku cedułą ktorą do drzwi na gospodzie mej przybyto'.

${ }^{31}$ Jan. 5, 1572. Warszawa. Client M. Sawicki letter to Radvila the Red, AR, dz. V, t. 344, nr. 13980.

${ }^{32}$ Ca. 1548 (place unknown). Sigismund Augustus letter to Radvila the Red, BN, mf. nr.3659.

${ }^{33}$ Aug. 15, 1548. Korczyn. Radvila the Black letter to Radvila the Red, AR, dz. IV, t. 34, kop. 497.

${ }^{34}$ Aug. 20, 1550. Kraków. Sigismund Augustus letter to Radvila the Red, BN, mf. nr. 3659, k. 140.

${ }^{35}$ There are some messengers fixed in the letters of Radvila the Red's clients : Fedorka (June 29,1572. Knyszyn, the Treasurer (podskarbi) of the GDL Laurynas Vaina letter to Radvila the Red, AR, dz.V, t. 444, nr. 17689), Chaniec (June 11, 1569. Lublin. Client Mikałaj Naruszewicz letter to Radvila the Red, AR, dz. V, t. 223, nr. 10263), Budylko, Raczko, Chorażycz, Zymbowski (from 1568 to 1572 M. Sawicki letters to Radvila the Red, AR, dz. V, t. 344, nr. 13980). 
to tell or to give the message as soon as possible. In the second case they also pleaded Radvila the Red's case when they passed on his messages.

\section{The Form of Letters}

The communication can be described as giving some message with the help of some symbols. In correspondence 'underlying consciousness' is conveyed with the help of signs. It determines the structure and content of the information in the wide sense (straightforward information and also emotional-psychological attitudes). That is why the form, style of a letter are important parts in stating the communication type between Sigismund Augustus and Radvila the Red.

It is very difficult to categorize the type of letters because of their very different content. Friendly, close letters dominate. ${ }^{36}$ Emotional attitudes are shown in a narrative description. There are also different elements of other types such as requests, instructions, gratitudes. When Radvila's mother, Barbora Radviliene (April, 1550) and her daughter, Queen of Poland, Barbora Radvilaite (May, 1551) died, the king and Radvila exchanged letters of condolence. After the death of Barbora, the type of letters changed slightly. Those were more conventional, friendly letters (1551-1572).

Rules of composition are kept very clearly in the correspondence. All parts typical of sixteenth-century letters are present, such as inscription, salutation, eschatocol. The epistolographic normativism of Sigismund Augustus letters was influenced by the scribes of his chancery who used a typical formula of address to the senator, ${ }^{37}$ 'wielmożny nam zwłaszcza miły' ${ }^{38}$ Only in the letters from the ruler to Radvila the Red are some very warm addresses to be found, such as 'panie podczaszy'39 and 'miły panie wojewoda'. ${ }^{40}$ An exceptional attitude towards Radvila is revealed by an exceptional form of address. A formulaic

${ }^{36}$ Correspondence of that type dominates in 1546-1551.

${ }^{37} \mathrm{~K}$. Mroczek, Tytulatura w korespondencji staropolskiej jako problem stosunku między nadawcą a odbiorcą. Pamiętnik literacki, nr. 2, 1978, 139.

${ }^{38}$ Such inscription is used to begin Sigismund Augustus letters to Radvila the Red (Feb. 11, 1549. Piotrkow; Feb. 11, 1549, Korczyn, etc.), BN, mf. 3654-3659.

39 Oct. 24, 1548. Piotrkow. Sigismund Augustus letter to Radvila the Red, AR, dz. II, nr. 23.

${ }^{40}$ Kaniewska, Niektóre, p. 103. 
term of address is preserved in Radvila the Red's letters to the ruler. Dictated letters usually started 'Najasnieyszy m. k. panie a panie moy m.' In letters written in his own hand he added some epithets such as 'dear', 'eternal benefactor'. ${ }^{41}$

The eschatocol of the above mentioned correspondence is typical: Sigismund Augustus wishes Radvila good health, Radvila the Red is 'ready to serve him humbly.'

The amount of correspondence is not equal on both sides. Letters from the king to Radvila the Red vary in length from two to three sheets. Form variation is characteristic of the letters of Sigismund Augustus. His letter to Radvila the Red very often finishes with a postscript or 'a secret royal note'. Letters written by the Chancellor are much longer, especially written in his handwriting (even up to 12-16 sheets) and they are complete.

The majority of the letters are written in Polish (the language of addressees) with Latin insertions. A score of letters, similar to official ones, are written in Ruthenian, typical of the Grand Duchy of Lithuania.

According to the stylistic attitude the correspondence of those two persons reminds more of a dialogue. The king did not send orders or instructions (which were very few) but exchanged opinions, asked for advice. An air of unquestionable authority which could be expected from traditional king and nobleman relations is not felt here. This kind of address was usually practised by the king in respect to royal persons as equal in correspondence.

\section{The Content of Letters}

The first function of the correspondence - communication between two persons - is made concrete by the content of letters. If the form of letters allows us to describe the means of communicating sense then the content shows what sense was conveyed, its importance to every addressee. At the same time it reveals the mechanisms of significance and cognition.

A varied inner composition of the letter is peculiar to the correspondence of Sigismund Augustus and Radvila the Red. Usually at the beginning the ruler discusses the letters he received from Radvila, then he adds new information, requests or instructions. In the letters written by Radvila discussions were replaced by expressions of gratitude, and instructions by new

${ }^{41}$ Dec. 9, 1547. Dubingiai. Radvila the Red letter to Sigismund Augustus. AR, t. 496, kop. 28. 
requests. This diversity of form conditioned the variety of topics discussed in the letters. At least two or three topics were broached in every letter.

The information of all letters can be divided into five parts:

1) Radvila family affairs (sisters, mother, cousin, brothers); 2) political business; 3) attention to Radvila's person; 4) instructions, advice, requests, patronage; 5) presents, expressions of gratitude.

\section{Affairs of Radvila the Red's Family}

In the early correspondence (1546-1551) these received the greatest attention. This is all connected with the figure of Barbora Radvilaite. Barbora was important in the social rise of the Radvila family; she was Sigismund Augustus' only real love, she helped him to become an independent ruler, to get free as a man from the care of his mother Queen Bona.

From the beginning until 1549 initiative lay with the king. Throughout the autumn and winter of 1548 he was filled with fear lest Barbora be poisoned. In November alone Radvila received eight letters from the king instructing where Barbora is allowed to go, how to guard her, what dishes she can drink water from, who is not allowed to get close to her, etc. ${ }^{42}$

The position of Radvila the Red changed when Barbora Radvilaite arrived in Kraków. The influence of Radvila the Black, Marshal of the Grand Duchy of Lithuania, over the king increased, and rivalry among the Radvilas began. To the requests of Radvila the Red to allow him to come to the king Sigismund Augustus answered that he was more useful in the Grand Duchy. ${ }^{43}$ Barbora tried to correct the situation by maintaining special friendship with her brother ${ }^{44}$. Writing or dictating letters to Radvila the Red she did not keep to demands, she addressed him 'dear brother' and she referred to herself in the singular.45 The king even started to control his wife's letters to Radvila,

${ }^{42}$ The letters of Sept.-Oct. 1548. Piotrkow. Sigismund Augustus to Radvila the Red, BN, mf. A 1927, k. 50-95.

${ }^{43}$ Baliński, Pisma, t. 1, p. 240.

${ }^{44}$ Oct. 23, 1549. Kraków. Barbora Radvilaitè letter to Radvila the Red. Barbora wrote: 'co bratu o siostrze rozumieć się godli nie ynaczey iedno jakobyśmy tecz z domu w. m. nie wyszli bo my o tym myślemy jakobyśmy w szadzie w. m. pomocni być mogli’, AR, dz. III, nr. 29.

${ }^{45}$ The Queen's secretary S. Koszucki informed Radvila the Red about it and asked not to be angry that the Queen: 'pisze Ja a nie my (...) a to jest j. m. wolia abych inaczej do w. m. nie pisał', Baliński, Pisma,t. 2, s. 17. 
read his letters to his sister. Sometimes he dictated the letters to the brother instead of Barbora. ${ }^{46}$ Only when Barbora got ill did the king start addressing the brother-in-law more often.

After the coronation the last more intensive stage of correspondence (March-June 1551) began. Sincerity, human pathos and a great hope for Barbora's recovery typify the king's letters to his brother-in-law in that period. After the Queen died, the main question concerned about the place where she should be buried. Sigismund Augustus did not pay attention to a Radvila the Red's rather insistent tone of the letter: 'for God's sake do not put her body there [...] among bodies of other kings' ${ }^{47}$ Still Radvila had to obey to the king's will to bury the Queen in Vilnius. ${ }^{48}$

There is very little information in their correspondence about other members of Radvila family: the mother of Radvila the Red, his sister Ona, his cousin Jonas Radvila, his wife and sons. Mostly they are mentioned when some matter arises concerning weddings, funerals or new social positions. Only Barbora Radvilaitë's affairs were most important to Radvila and to the king.

\section{Political Affairs}

Every letter from both correspondents gave information of some kind. As time passed, its character changed. Early correspondence was connected with the royal marriage: Sigismund Augustus informed Radvila about business in the Seym, about winning over hostile senators, about the behaviour of Queen Bona. The king was interested in the affairs of the Grand Duchy. From Radvila he received news about the death of the Vilnius voivode, the behaviour of the Vilnius Chapter in

${ }^{46}$ Apr. 28, 1550. Above mentioned S. Koszucki affirmed that the letter to the brother was written not by Barbora but was dictated by the king 'sam pisać roskazał w zamknieniu, tam gdzie niebył jedno on a ja. A gdym ji napisał oboje ji przeczytało, tamże ji jej k. m. w ręku jego k. m. podpisała', S. Koszucki marked this letter with a cross secretly and warned Radvila 'znak taki uczinił, racz w. m. wiedziecz', that the letter was not written by Barbora. Baliński, Pisma, t. 2, p. 125.

${ }^{47}$ Ibidem, p. 243.

${ }^{48}$ Radvila the Black advised his cousin to bear grief with dignity, should it come, because 'tedy by nieprzyjacziel ucieszył, a minąc tego in toto trudno gdy tak czas pryniósł a rzeczy za się taki...', May 20,1551. Brest, Radvila the Black letter to Radvila the Red. AR, dz. IV, t. 35, kop. 501. 
the Goštautas chapel, the behaviour of local noblemen and others. In fact, Radvila was ruling the Grand Duchy at that time. Asked by the ruler, he informed the king about the state of noblemen, their attitude towards the union, opposition to the Radvilas; ${ }^{49}$ sometimes he retold whole conversations, but he did not yet advise the king boldly. ${ }^{50}$

After the death of Barbora Radvilaite, Radvila the Red lost his first position in the Grand Duchy of Lithuania. Until 1565 Radvila the Red and his cousin were the main advisers in the Grand Duchy of Lithuania for.Livonian events. ${ }^{51}$ In 1562 the chief of the united army, Florian Zebrzydowski, wrote that the king did not do anything without Radvila's advice'. ${ }^{52}$

Radvila's position got especially strong after Radvila the Black died. After 1565 the king recognized Radvila the Red's leading position in foreign affairs of the Grand Duchy. Sigismund Augustus agreed that Radvila the Red sent envoys to Muscovy, informed about the news he had received from the pope, called him 'best informed with affairs of Moscow enemies'. ${ }^{53}$

At the end of Sigismund Augustus' reign the tsar was informed by the envoys of Moscow that 'all the king's Lithuanian land depends on the Voivode of Vilnius Mikalojus Radvila and he is free to give and take, and all the land obeys him and the starosta of Žemaitija'. ${ }^{54}$

However, after the Union of Lublin (1569) Radvila the Red changed his attitude towards the king. Radvila's memorial to the king is quite open; it was written by M. Sawicki on December 17, 1569. That was Radvila's considered opinion of the political situation in the Grand Duchy of Lithuania after the Union and of his own position. He strictly rejected ideas for the ruler's elections saying that if you want to talk about the way how to elect but not about the elections themselves, then this

49 July 2, 1550. Piotrkow. Sigismund August letter to Radvila the Red, BN, mf. nr. 3659, k. 132.

${ }^{50}$ One of the pieces of advice given by Radvila concerning law courts that every Voivode could judge in his own district was heeded and accepted by the king, Baliński, Pisma, t. 2. p. 238.

${ }^{51}$ Lachowicz, Listy,p. 137.

52 J. Jasnowski, Materiały do działalności wojskowej Floriana Zebrzydowskiego. Przeglad Historiczno-Wojskowy, t.9, z. 2, 1937, 283.

${ }^{53}$ Korespondencye Jana Karola Chodkiewicza, ed. Wł. Chomentowski, Warszawa, 1875, 111-13.

${ }^{54}$ Łulewicz, Mikotaj Radziwitt, p. 327. 
way has existed in the Polish statute' ${ }^{5} \mathrm{He}$ was more apprehensive that after, the election of a king, the regional land charters of former rulers might change..$^{56}$ In 1570 the king wrote an answer to Radvila through the same Sawicki, denying the power of a rulerelect to unite the crown lands with the personal lands they might have. The Voivode has to believe that the Union of Lublin ensures 'all privileges, donations, inscriptions which have been given to any estate or persons any time' ${ }^{57}$ The king was more waiting for Radvila's arrival into Warsaw Seym that 'confidenter namawiacz y naziczlywey radzie w. m. którą J. k. m. zawsze po iego m. znał przestawacz chce' Sigismund Augustus expected Radvila to help implement some reforms he had thought out concerning the return of the royal lands ('we have lost a lot of our lands'), the discussion of a new way of elections. In the sixth article of his responses the king insistently invites the Voivode to come to the Seym, willingly accepting Radvila's devotion which 'his Royal Majesty had recognized with reference to his person.' The relationship remained quite friendly and open in the last years of Sigismund Augustus' reign.

\section{Attention to Radvila's Person}

We will discuss the king's attitude towards his brother-in-law's health, how Sigismund Augustus reacted to his illnesses. As can be seen from his letters to the king, Radvila never complained about his health and the length of his life ( 72 years) allows us to presume that he was not very sickly. At the same time his cousin Radvila the Black was greatly ill in the lasts months and he constantly pointed to his pains, inability to walk, treatment with mercury. ${ }^{58}$ At the beginning Sigismund Augustus informed himself about this topic, in 1549 he was suffering with a cough, in 1553 he informed about his fever; ${ }^{59}$ later they learnt about the king's health from his clients in the court.

In 1552 the king was informed about 'a great illness' of Radvila the Red by his cousin Radvila the Black. The ruler sent

${ }_{55}$ Dec. 17,1569 . Petition from the Vilnius Voivode to the king written by M. Sawicki, AR, dz. II, nr. 62.

${ }^{56}$ M. Jučas, Kas prieštaravo unitarinès respublikos idejjai Liublino seimo išvakarèse, Kultūros barai, nr. 6, 1997, 52.

${ }^{57}$ Feb. 8, 1570. The king's answer to the Vilnius Voivode petition, AR, dz. II, nr. 63.

${ }^{58}$ See Lachowicz, Listy, passim.

${ }^{59}$ June 15, 1549. Piotrkow. Sigismund Augustus letter to Radvila the Red, BN, mf. nr. 3659, k. 45; Lachowicz, Listy, p. 53,55. 
a special messenger who had to inform him about the state of the brother-in-law's health ${ }^{60}$ 'for great favour of his Majesty'. The king showed a greater concern in 1562, when Radvila wrote himself about his illness. Perhaps his illness recurred because Sigismund Augustus noted 'as it was in Varèna' and ordered him to listen to his doctor's advice. When he received the description of this illness, he sent his sister princess Kotryna's doctor Alexander Paruez, and he also gave spare horses to change 'in order not to take any time because such illness is usually merciless' ${ }^{61}$

Nevertheless Sigismund Augustus was not pleased by Radvila the Red's plea of illness in Lublin in 1569. In April 30 of the same year he had to swear allegiance to the king for his estates in Podlasie and to recognize the annexation of Podlasie and Volyn' to Poland. But Radvila the Red excused himself for not coming because of his illness. Radvila's letter, which does not survive and his secretary Andrius Volanas' audience with the ruler, gave results, and the king at least pretended to believe that Radvila was ill. Volanas wrote: the king "believes that Radvila the Red is ill because when he was still here in Lublin, he was a little ill. And he at once asked about the illness and medicine'. ${ }^{62}$ Later the king did not inquire about Radvila's health.

The relationship between the two men changed after the Union of Lublin, reflecting their changed position in society. As was mentioned above, Radvila the Red was the most powerful man in the Grand Duchy of Lithuania at that time and his position in the 1570 Warsaw Seym was very important to Sigismund Augustus. Perhaps that was why the king personally gave instructions to find comfortable quarters for the Vilnius Voivode. ${ }^{63}$

At the end of his life the ruler's attitude towards Radvila changed a little, but friendship and trust still remained.

${ }^{60}$ Jan. 15, 1552. Lukow. Sigismund Augustus letter to Radvila the Red, BN, mf. nr. 3654, k. 1.

${ }^{61}$ Jan. 26, 30, 1562. Rudninkai. Sigismund Augustus letter to Radvila the Red, BN, mf. nr. 3654, k. 64-65.

${ }^{62}$ A. Volanas, Rinktiniai raštai. Ed. M. Ročka, I. Lukšaitè, Vilnius, 1996, 348.

${ }^{63}$ March 21, 1570. Warszawa. M. Savickis letter to Radvila the Red. Radvila the Red gave this task to his client M. Savickis who informed in the letter that the king himself tried 'abyś w. m. wczesnie y wedlie stanu swego stal zatrzymal na sie folwark fokarowski, niedaleko miasta iest, tak, jako w Wilnie od Ostrej Bramy do dworu w. m.' AR, dz. V, t. 344, nr. 13980. 
Instructions, Requests, Protections

Instructions, requests and their tone show a communicative character. As the ruler and Radvila the Red were standing on different steps of the social hierarchy, Sigismund Augustus usually instructed in the letters and Radvila the Red asked. It is interesting that the king's instructions were not always 'royal'. First of all they were not orders but more gently formed instructions, even so after giving them the king always expected to have them fulfilled resolutely.

Radvila the Red was not very modest in his letters to the king. Material things dominated, he asked less advice: he asked for very different things starting with new stewards, finishing with protections for persons he was supporting. Sometimes he asked directly, sometimes through trustworthy persons - his sister Barbora, his clients. For all presents and requests that were fulfilled through the clients in the court, even the king's hand had to be kissed in the name of Radvila the Red. ${ }^{64}$

Exploiting Barbora Radvilaite's influence, Radvila asked the king for the highest office of the Grand Duchy of Lithuania (that of Chancellor) and for the Kaidanov estate which had been returned to the monarch by the Goštautas family.

After Barbora's death the king started receiving Radvila the Red's letters asking to pay all his sister's debts. He was not very successful in persuading the king to pay Barbora's debt to one Konratas (perhaps the Vilnius burgher Kondrat Knoff) as if redeeming Radvila's pawned golden chains and horse's saddles. He asked that two years after the Queen's death. Sigismund Augustus did not want to hear anything about it because all Barbora's debts had been written down into a separate register and orders were given to pay them all ${ }^{65}$ In April 1553 after one more try to get money for Barbora's debts Radvila gave order to his client Mikołaj Trzebuchowski to talk about this debt and even sent a debt bill. But the king did not see 'a signature in the queen's

${ }^{64}$ Nov. 31, 1548. Piotrkow. The Queen's marshal, Gabriel Tarło, wrote to Radvila the Red: 'raczył mi pisać abych od w. m. Jego k. m. ręke czałował. Tom uczynil rad. J. K. M. to wdziecznie y z wielką laską od w. m. przyiącz raczil', AR, dz. V, t. 397, nr. 16105; Radvila the Black did the same, Sept. 4, 1547. Piotrkow, Radvila the Black letter to Radvila the Red, 'a za ten dodatek, który mi jego k. m. ilość poslał, w. m. racz rękę odemniej j. k. m. całować jako memu m. Panu', AR, dz. IV, t. 34, kop. 497.

${ }^{65}$ March 25, 1553. Kraków. Sigismund Augustus letter to Radvila the Red, BN, mf. nr. 3654. k. 35. 
handwriting' on the debt bill and the stamp had letters ' $B$. $g$. but not $B . R$. as the king remembers'. The client heartily suggested not to ask for payment of this debt and returned all sent documents. ${ }^{66}$

Radvila's high position in society required an income sufficient for him to maintain that rank. Especially great expenditure was demanded by the position of hetman which he requested. In 1550 his cousin Radvila the Black reminded him of all 'advantages' of being a hetman steward. ${ }^{67}$ The king, however, always tried to send the money necessary for military expenditure as soon as possible ${ }^{68}$.

A little later there were requests to allow to float salt without duties from Gdańsk and Königsberg ${ }^{69}$ to return not clear 'summa iusticia'70, to give the office of hetman, new villages or new services for people and many more others. In the 1569 petition there were even four great requests to the king: Radvila asked to free from taxes the Borisov estate reminding about great losses for the state's wealth and about his estates that he pawned; to allow his elder son Mikalojus to get more profitable estates than Bobruisk and Liuboszczany, which were in poor condition, to give more money for a proper trip to the Seym of Warsaw. ${ }^{71}$ As he wished to widen the Biržai estate he asked the king to allow him to buy or rent even 1,000 valakas in Upyte district. ${ }^{72}$

During the last months of the king's life, Radvila intensively followed his state of health, he wanted to come himself to the

${ }^{66}$ Apr. 25, 1553. Kraków. M. Trzebuchowski letter to Radvila the Red, AR, dz. V, t. 408, nr. 16509.

67 ، ... trzeba na to wiele sług i niemałego obozu, nieprzystoi na krzywym przyjechawszy hufów szykować. Owo u kogo rubli, u tego i rozum, a ubogi kiep, jako dawno', Ibidem, p. 157.

${ }_{68}$ June 21, 1561. Lukiškès. Radvila the Black letter to Radvila the Red (There was some inconvenience because the money was not collected in time. Such was the situation in 1561, but Sigismund Augustus announced through Radvila the Black that the money would be received soon and sent), AR, dz. IV, t. 35, kop. 502.

${ }^{69}$ Jan. 31, 1558. Wiażyn. Radvila the Red letter to Sigismund Augustus AR, dz. IV, t. 34, kop. 495.

${ }^{70}$ Nov. 3, 1555. Wiażyn. Radvila the Red letter to Sigismund Augustus, AR, dz. IV, t. 34, kop. 496.

${ }^{71}$ Dec. 17, 1569. Vilnius. Petition from the Vilnius Voivode to the king written by M. Sawicki, AR, dz. II, nr. 62

72 'Na upytskich włok tysiąc dałby thy pieniądze, a co wolnye zbywa niechby w dzierzawie trzymał’, Ibidem. 
court. His clients sent letters to Radvila in a hurry informing him about the king's health and all attempts to present Radvila's letters concerning giving him the Borchev estate. But the king still dallied. M. Sawicki was persistent and the Sub-treasurer of the Grand Duchy of Lithuania, Laurynas Vaina's requests to sign documents were put aside by the ruler; 'we could not be successful in asking him to sign either in Warsaw or on the way,' Sawicki wrote and at once suggested to him to come as soon as possible because everything could fall to the Firleis. ${ }^{73}$ Radvila did not arrive or did not come in time and the documents were not signed. Though Sawicki and Vaina had written the texts of the privileges concerning Borchev, 'we could not bring everything till the morning and seeing all this, milord Vaina pleaded in tears 'not to be angry because they were making all possible efforts. ${ }^{74}$ Radvila the Red received some news that on the last days the king signed different documents to others, both Poles and Lithuanians, except only his. ${ }^{75}$

In his letters Radvila paid great attention to patronage matters, he tried to get services to the people that were favourable to him, he created a client system. The people that he patronized had different social positions and family connections with Radvila.

He did not often ask the king for favours for his family members but in the received privileges for new stewards he notes his father's merits. Perhaps he put in order family business in private connections with the king. ${ }^{76}$

After becoming the king's brother-in-law he constantly asked favours for his people. In 1550 Sigismund Augustus spoke

73 June 29, 1572. Knyszyn. M. Savickis letter to Radvila the Red 'aby w. m. niepytając się królia po dwu niedzieliach w kilka dni' to come as soon as possible, AR, dz. V, t. 344, kop. 13980.

${ }^{74}$ July 8, 1572. Knyszyn. M. Sawicki letter to Radvila the Red, Ibidem.

${ }^{75}$ The Sub-treasurer of the Grand Duchy of Lithuania L. Vaina explained in his letter to Radvila that it was so but the documents Radvila wanted were 'ze wszytkym pierwy dzien ode dnia a potem do Knyszyna odlożył', in Knyszyn the king asked for these documents 'alie nam poslanca w. m. Fiedorzku zatrzymywacz niewidziało' and they sent them. June 29, 1572. Knyszyn. L. Vaina letter to Radvila, AR, dz. V, t. 444, nr. 17689.

${ }^{76}$ The letters reflected the final results of their conversations, the king informed about the place of steward, sending money to his sons, Apr. 30, 1567. Knyszyn, July 15, 1567. Knyszyn. Sigismund Augustus letters to Radvila the Red, BN, mf. nr. 3654, k. 143, 145. 
to Barbora that he kindly takes of Radvila's but he usually patronizes such people the king 'does not care for and that is why he asks at least in the letters to consult him who is going to be patronized' and to do it more rarely. ${ }^{77}$ There were some misunderstandings when the king fulfilled Radvila's request but he informed personally 'confidenter' about his dissatisfaction with the protected person. ${ }^{78}$

The list of protected is really impressive. In the letters that remained he asked for more than 20 of his clients. Radvila tried to get new estates or new stewards for them. That had to make his own position stronger.

\section{Gifts and expressions of gratitude}

As it can be seen Radvila asked a lot from the king. But did the saying 'the more you ask, the more you get' justify itself ? A well-known lawyer of those times Piotr Roysius wrote in one of his epigrams dedicated to Radvila that the king fulfils all Radvila's golden and copper aspirations and he never refuses. ${ }^{79}$ But what was the real situation? The correspondence more reflects minor presents of the king to Radvila the Red and they were like 'proofs of friendship' and besides them the nobleman received money, different permissions, high stewards. Other documents fill various gaps in the chronological order of letters.

There were some other donations except those bigger ones: permission to hunt in the king's forests or to live in Vilnius Lower Palace. Minor presents reflected warm relationship between them. In 1548 the king sent an Italian hound ${ }^{80}$ through his horseman; in 1549 Radvila the Red received a note from the king allowing him to take a tun of wine from some Vekhas in Vilnius. ${ }^{81}$ Later Sigismund Augustus sent a gold-framed picture as he wanted to show his favour to the Voivode of Trakai. ${ }^{82}$

${ }^{77}$ Baliński, Pisma, t. 2. p. 116.

${ }^{78}$ (Unknown time and place), Radvila the Red letter to Sigismund Augustus, AR, dz. IV, t. 34, kop. 495.

${ }^{79}$ Petri Royzii Maurei, Carmina, Cracoviae, pars 2, 1900, 104.

${ }^{80}$ July 22, 1548. Kraków. Sigismund Augustus letter to Radvila the Red, BN, mf. nr. A 1927, k. 27.

${ }^{81}$ Jan. 26, 1549. Piotrkow. Sigismund Augustus letter to Radvila the Red, BN nr. 3659, k. 28.

82 July 16, 1552. Gdańsk. Sigismund Augustus letter to Radvila the Red, BN, nr. 3654, k. 23. 
Table 2 Donations of Sigismund Augustus to Radvila the Red in $1544-1569$

\begin{tabular}{|c|c|c|}
\hline Year & Donation & Source \\
\hline & Money & \\
\hline 154805. & 500 zloty to pay debts & BN, mf, nr. Al927, k. 10. \\
\hline 154808. & 500 zloty for Barbora's escort to Poland & $\mathrm{BN}, \mathrm{mf} . \mathrm{nr} . \mathrm{A} 1927, \mathrm{k} .37,41$ \\
\hline 1549. & 200 zloty & $\mathrm{BN}, \mathrm{mf}, \mathrm{nr} .3659, \mathrm{k} .45$ \\
\hline 155003 & 400 zloty & $\mathrm{BN}, \mathrm{mf} . \mathrm{nr} .3659$, k. 90 \\
\hline 1551. & $\begin{array}{l}3000 \text { Hungarian ducats (after Barbora's } \\
\text { coronation) }\end{array}$ & Kuchovičius, Barbora., p. 182. \\
\hline since 1559 & $\begin{array}{l}\text { every year } 700 \text { Lithuanian kopas grosh when the } \\
\text { king arrives to the GDL } \\
\text { Exemption from taxes }\end{array}$ & LM, 37, 1. 307. \\
\hline 155806. & for 3 years from Samiliškès estate & $\mathrm{LM}, 37,1.254 \mathrm{v}$ \\
\hline 155806. & $\begin{array}{l}\text { from a part of income of his ruled Lida and } \\
\text { Bielica }\end{array}$ & $\mathrm{LM}, 37,1.254 \mathrm{v}$ \\
\hline 155806. & $\begin{array}{l}\text { from a part of income of customs and inns by } \\
\text { Mozyr }\end{array}$ & LM, 37, 1. 255 . \\
\hline 155901. & $\begin{array}{l}\text { to give a half of the oats quota owed by Lida } \\
\text { and Bielica }\end{array}$ & LM, 37, I. 307. \\
\hline 156006 & from all silver taxes that had not been paid & LM, $42,1.47 \mathrm{v}$. \\
\hline 15670215 & from Borisov taxes for 3 years & LM, $51,1.60-61$ \\
\hline 1567. & from all unpaid taxes & AR, dz. XI. nr. 19, k. 44 \\
\hline 1569. & $\begin{array}{l}\text { from Borisov and Mozyr taxes for } 5 \text { years } \\
\text { Received stewards }\end{array}$ & Respons, AR, dz. II, nr. 63 . \\
\hline 1544. & The Cup-bearer of the GDL & Lulewic z, Radziwill, p. 320-328. \\
\hline 1546. & The Huntsman of the GDL & Lulewicz, Radziwill, p. $320-328$. \\
\hline 1548. & a privilege to rule the GDL on king's absence & Lulewicz, Radziwill, p. 320-328. \\
\hline 1550. & TheV oivode of Trakai & Lulewic z, Radziwill, p. 320-328. \\
\hline 1556. & The Grand Hetman of the GDL & Lulewic z, Radziwill, p. 320-328. \\
\hline 1565. & $\begin{array}{l}\text { The Voivode of Vilnius, the Chancellor of the } \\
\text { GDL } \\
\text { Services and estates that Radvila got to govern } \\
\text { and own in perpetuity }\end{array}$ & Eulewic z, Radziwill, p. $320-328$. \\
\hline 1547 & Lida, Bielica (to govern) & $\begin{array}{l}\text { LM, } 31, \quad \text { I. } 118 ; \text { Lulewicz, } \\
\text { Radziwill, p. } 320-328 .\end{array}$ \\
\hline 1550 & Koidanov (the right to inherit) & Łnlewic z, Radziwill, p. $320-328$. \\
\hline 1551. & Sa miliškès (to govern) & $\begin{array}{l}\text { Lm, } 28, \quad \text { 1. } 89 \mathrm{v} ; \quad \text { Lulewicz, } \\
\text { Radziwill, p. } 320-328 .\end{array}$ \\
\hline 1553.I.4. & $\begin{array}{l}\text { Parech district (for ever) connected with } \\
\text { Koidanov }\end{array}$ & L M, 35, 1. 119 \\
\hline 1556. & Mozyr (to govern) & L M, 35, 1. 119. \\
\hline 1558. & Stankovsk estate (to govern) & LM, 37, 1. 227. \\
\hline 1561. & $\begin{array}{l}18 \text { valakas in king's estates of Eišiškés and } \\
\text { Radun }\end{array}$ & LM, $39,1.246,248$ v. \\
\hline 1564. & Bielica (the right to inherit) & AR. dz. VIII, nr. 23. \\
\hline 15680520 & $\begin{array}{l}10 \text { villages ( } 250 \text { valakas) in Lida district (the } \\
\text { right to inherit) }\end{array}$ & LM, 51, 1. $141-142$. \\
\hline 1568. & the village of Molgoviche in Lida district & AR, dz, XI, nr. 19, k. 40. \\
\hline
\end{tabular}


Conclusions

The correspondence between the ruler of the Grand Duchy of Lithuania and Poland Sigismund Augustus and the Lithuanian nobleman Radvila the Red included 26 years of communication between these two persons. Kinship, the men's similar social status and Weltanschauung influenced their liberal type of communication.

The correspondence of Sigismund Augustus and Radvila the Red reflected the relationship of two close people. At the beginning of their relationship, the factor of Radvila's sister Queen Barbora Radvilaite was very important and significant. Radvila was the main addressee of the king of that time.

Changes in their mutual relations are illustrated by a decrease in the number of letters from the king to this brotherin-law after the Queen's death. However, since Radvila the Red put great efforts into the relationship, he did not disappear from the king's horizon and constantly reminded Sigismund of his existence with different requests.

Because the king's strong memories of Barbora and Radvila's constantly reminding the ruler about him, Radvila the Red not only maintained the position he had won, but even became the first person in the Grand Duchy of Lithuania through the king's support. Fourteen years after Barbora's death he received the position of Vilnius Voivode and Chancellor of the Grand Duchy of Lithuania. Thenceforth Radvila the Red felt greater confidence in himself and sometimes he communicated with the king as equal.

Difference in political orientations (disagreements for the Union of Lublin) harmed their relationship. At the end of Sigismund Augustus's life their relationship became as it had been at the beginning. Psychological aspects and their changed position in the state were important at that time. 